\title{
ANALISIS HUBUNGAN ANTARA RELIGIUSITAS DAN LINGKUNGAN SEKOLAH TERHADAP MOTIVASI BELAJAR SISWA KELAS XI SMA NU BANCAR
}

\author{
Lu'lu'ul Khusnanut Thohir ${ }^{1}$, Mohamad Arief Rafsanjani ${ }^{2}$ \\ Prodi Pendidikan Ekonomi, Universitas Negeri Surabaya \\ tohir6678@gmail.com ${ }^{1}$, mohamadrafsanjani@unesa.ac.id ${ }^{2}$
}

Website : https://jurnal.uin-antasari.ac.id/index.php/ptkpend/index

Received: 28 Mei 2021; Accepted: 07 Juni 2021; Published: 14 Juni 2021

\begin{abstract}
The decrease in learning motivation is one of the factors that can hinder learning activities. The purpose of this study was to determine the effect of religiosity and the influence of the school environment on students' learning motivation. This research is classified as a quantitative research using ex post facto research methods. This study has a population that comes from all students in class XI at SMA NU Bancar with a saturated sampling method so that all students in class XI at SMA NU Bancar are involved in the research sample, totaling 46 students. The data analysis technique in this study used multiple linear regression test. After going through the testing process, the results of the assessment were obtained (1) The religiosity variable had a positive and significant influence on the learning motivation variable in class XI students at SMA NU Bancar. (2) The school environment variable has a positive and significant effect on the learning motivation variable in class XI students at SMA NU Bancar.
\end{abstract}

Keywords: Religiosity; School Environment; Learning Motivation

\begin{abstract}
ABSTRAK
Menurunnya motivasi belajar menjadi salah satu faktor yang dapat menghambat kegiatan pembelajaran. Tujuan dilaksanakannya Penelitian ini adalah Untuk mengetahui pengaruh religiusitas serta pengaruh lingkungan sekolah terhadap motivasi belajar siswa. Penelitian ini tergolong dalam penelitian yang berjenis kuantitatif dengan menggunakan metode penelitian ex post facto. Penelitian ini memiliki populasi yang berasal dari seluruh peserta didik kelas XI di SMA NU Bancar dengan metode sampling jenuh sehingga seluruh peserta didik yang ada kelas XI SMA NU Bancar dilibatkan menjadi sampel penelitian yang berjumlah 46 siswa. Teknik analisis data dalam penelitian ini menggunakan uji regresi linier berganda. Setelah melalui proses pengujian diperoleh hasil hasil penilaian (1) Variabel Religiusitas memiliki pengaruh positif dan signifikan terhadap variabel Motivasi belajar pada peserta didik kelas XI SMA NU Bancar. (2) Variabel Lingkungan Sekolah memiliki pengaruh positif dan signifikan terhadap variabel Motivasi Belajar pada peserta didik kelas XI SMA NU Bancar.
\end{abstract}

Kata Kunci: Religiusitas; Lingkungan Sekolah; Motivasi Belajar

\section{PENDAHULUAN}

Pendidikan merupakan salah satu aspek yang berkaitan erat dengan kehidupan manusia sehari-hari serta menjadi dasar yang digunakan untuk merencanakan dan mewujudkan sebuah kegiatan pembelajaran. Kegiatan pembelajaran ini dilaksanakan dengan tujuan untuk memberikan pengetahuan baru bagi peserta didik serta membantu untuk mengasah potensi yang ada pada diri mereka sehingga dapat memliki 
kemampuan yang berkaitan dengan kecerdasan, kedewasaan, ahklak mulia, spiritual keagamaan, pengendalian diri, serta berbagai macam skill yang mampu memberikan kemanfaatan bagi pribadi mereka sendiri, maupun kepada orang lain di lingkungan masyarakat. Era globalisasi yang disertai oleh pesatnya kemajuan di bidang teknologi informasi dan komunikasi secara tidak langsung memberikan suntikan motivasi baru bagi peserta didik dalam meningkatkan kualitas belajar mereka untuk meningkatkan kemampuan dalam menghadapi persaingan dalam dunia kerja pada masa revolusi industri 4.0 yang semakin ketat ini.

Tohidi \& Jabbari (2012) mendeskripsikan Motivasi sebagai suatu alat untuk Memberdayakan orang guna mencapai tingkat kinerja tinggi dan mengatasi hambatan untuk berubah. Menurut Sardiman (2018:85), motivasi belajar merupakan sebuah daya yang mampu menggerakkan diri siswa untuk melakukan kegiatan belajar, menjamin keberlanjutan dalam belajar, menentukan perencanaan belajar, sehingga dapat mencapai tujuan yang dicita-citakan dalam kegiatan belajar. Werang (2018) mendefinisikan pengertian motivasi belajar sebagai sesuatu yang dapat berperan menjadi faktor pendorong peserta didik untuk dapat secara aktif terlibat dalam kegiatan akademik, membuat mereka berusaha ketika mendapatkan kesulitan dalam belajar, dan menentukan berapa banyak waktu yang mereka berikan untuk belajar. Sedangkan Saputri, Aminuyati, \& Achmadi (2015) mengungkapkan bahwa Motivasi belajar merupakan sebuah dorongan maupun serangkaian usaha dari peserta didik untuk melakukan kegiatan belajar guna tercapainya tujuan pembelajaran melalui pengalaman yang mereka peroleh dari lingkungan sekitar. Motivasi ini sangat diperlukan bagi peserta didik, karena dapat mempengaruhi semangat mereka dalam belajar.
Wlodkowski \& Jaynes (2004:24) mengungkapkan bahwa motivasi belajar peserta didik dipengaruhi oleh empat hal utama, yaitu: budaya, keluarga, sekolah, serta diri anak itu sendiri. Nilai-nilai terkandung pada faktor budaya dipengaruhi oleh agama, undang-undang, peraturan mengenai pendidikan serta melalui harapan-harapan dari orang tua yang berkenaan dengan persiapan anakanak mereka dalam hubungannya dengan kegiatan pembelajaran. Hal tersebut akan berpengaruh terhadap motivasi belajar dari peserta didik. Menurut Wahyuningsih (2008) seseorang yang memiliki jiwa religius akan memiliki perasaan positif dalam kehidupannya. Salah satu perasaan positif seseorang tersebut tercermin dalam kebahagiaan hidupnya yang akan membuat seseorang tersebut memiliki kesehatan mental yang positif. Sebaliknya, seseorang yang kurang memiliki jiwa religius, maka dalam kehidupannya akan sering diliputi oleh perasaan cemas terhadap Tuhan, yang akan mengakibatkan pada kesehatan mentalnya menjadi negatif. Guven (2013) menyatakan bahwa agama dapat menjadi acuan dalam memotivasi manusia di segala bidang dan meningkatkan efisiensi manusia. Dengan kata lain, ajaran agama tidak hanya mengajarkan hal-hal yang bersifat ritual semata, melainkan juga mengatur hal-hal yang bersifat keduniawian, dimana agama juga mengarahkan individu termotivasi dalam menjalankan tugas dan kewajibannya, yang dalam hal ini adalah belajar.

Nashori \& Mucharam (2002:71) menyatakan bahwa tingkat religiusitas seorang muslim dapat dilihat berdasarkan seberapa jauh penghayatan, keyakinan, pengetahuan, serta pelaksanaan kewajiban mereka terhadap syari'at agama Islam. Seorang muslim yang mempunyai tingkat pemahaman agama yang baik pasti akan melaksanakan kewajiban yang ada pada syariat Islam. Dikarenakan menuntut ilmu menjadi salah satu kewajiban, maka kewajiban tersebut harus dilaksanakan 
dengan sungguh-sungguh bagi seluruh umat Islam. Amin (2020) berpendapat bahwa motivasi belajar yang muncul dalam diri seorang peserta didik berasal dari penanaman serta pemahaman dari nilai religius yang dipelajarinya. Motivasi tersebut dapat memberikan dorongan bagi mereka untuk senantiasa belajar serta mengembangkan diri terhadap keilmuannya sehingga dapat berujung kepada peningkatan prestasi bagi peserta didik tersebut.

Dalam penelitiannya, Nugrahini (2013) menyimpulkan bahwa tingkat religiusitas peserta didik memliki hubungan yang signifikan terhadap motivasi mereka dalam mempelajari agama Islam. Sehingga semakin tinggi tingkat religiusitas peserta didik maka semakin tinggi pula motivasi mereka untuk mempelajari agama Islam, begitu pula sebaliknya. Hanya saja penelitian diatas hanya befokus mencari hubungan antara religiusitas terhadap motivasi belajar sesuai dengan agama yang dianutnya, yaitu Islam. Sehingga diperlukan adanya penelitian lanjutan yang berfokus dalam mencari hubungan antara religiusitas terhadap motivasi belajar peserta didik secara umum pada seluruh mata pelajaran.

Faktor lain yang dapat mempengaruhi motivasi belajar peserta didik menurut Wlodkowski \& Jaynes (2004;24) adalah faktor lingkungan sekolah. Yusuf (2012:54) menyatakan bahwa Sekolah adalah sebuah lembaga pendidikan yang secara formal menyelenggarakan program pengajaran, bimbingan, serta latihan secara sistematis dengan tujuan untuk membantu mengembangkan potensi peserta didik, yang meliputi aspek intelektual, spiritual, emosional, moral, maupun aspek sosial. Sekolah juga termasuk dalam sebuah institusi sosial yang didalamnya terdapat suatu proses sosialisasi antar para anggotanya. Menurut pendapat Oktaviana (2015) Sekolah berperan sangat penting dalam meningkatkan kualitas pola pikir peserta didiknya, hal tersebut dikarenakan para peserta didik diajarkan berbagai macam disiplin ilmu pengetahuan dan keterampilan. Sekolah juga mempunyai pola relasi serta sistem sosial yang unik antar para warganya yang disebut dengan kebudayaan sekolah. Nurfirdaus \& Hodijah (2018) mengungkapkan bahwa Lingkungan sekolah berperan penting dalam melaksanakan pembentukan perilaku sosial bagi peserta didik, dari pembentukan perilaku sosial tersebut sehingga tujuan pendidikan dapat terwujudkan dengan maksimal. Seluruh warga sekolah harus mampu melaksanakan tugas yang mereka emban sesuai dengan status mereka. Kepala sekolah mengawasi dan membuat serangkaian kebijakan. Guru menjadi role model serta memberikan pengajaran kepada peserta didik. Begitupun dengan peserta didik yang harus mengikuti kegiatan pembelajaran dengan bersungguh-sungguh.

Penelitian Mantilia

menunjukkan hasil bahwa lingkungan sekolah memiliki pengaruh yang signifikan terhadap motivasi belajar peserta didik pada mata pelajaran Pendidikan Agama Islam di SMAN 1 Kibang. Palangda (2017) dalam penelitiannya juga menyebutkan bahwa lingkungan sekolah mempunyai pengaruh positif dan signifikan terhadap minat belajar Ekonomi pada peserta didik di SMK Negeri 4 Makassar, lingkungan sekolah juga mempunyai pengaruh yang sangat kuat terhadap minat peserta didik dalam mempelajari mata pelajaran Ekonomi. Kedua penelitian diatas hanya mencari hubungan pengaruh lingkungan sekolah terhadap motivasi mempelajari satu mata pelajaran secara spesifik saja, sehingga diperlukan adanya penelitian lanjutan yang membahas pengaruh variabel lingkungan sekolah terhadap motivasi belajar peserta didik secara umum berdasarkan mata pelajaran yang mereka pelajari di sekolah. 
Berdasarkan observasi dan hasil interview yang dilakukan dengan beberapa guru di SMA NU Bancar, tingkat religiusitas peserta didik disana dapat dikatakan cukup baik $\mathrm{Hal}$ itu dibuktikan dengan tingginya tingkat partisipasi peserta didik disana dalam menjalani beberapa kegiatan keagamaan seperti Sholat berjama'ah, Majelis Dzikir, maupun maupun kegiatan dalam memperingati Hari Besar Islam. Tak jarang para peserta didik mendapatkan tugas berguliran untuk menjadi pemimpin dalam kegiatan keagamaan tersebut dan dapat menjalankan tugasnya tersebut dengan baik. Selain itu, hasil belajar dari peserta didik juga cukup baik dalam menguasai mata pelajaran di bidang keagamaan diantaranya Al Qur'an Hadits, Fiqih, Bahasa Arab, maupun Aqidah Akhlaq.

Dalam kaitannya dengan lingkungan sekolah, kondisi lingkungan di SMA NU Bancar juga cukup baik untuk melaksanakan kegiatan pembelajaran. Kualitas infraskruktur penunjang kegiatan pembelajaran juga cukup baik serta menyesuaikan dengan perkembangan zaman. Kegiatan interaksi antar warga sekolah juga sangat baik karena hampir sebagian besar warga sekolah disana tinggal di wilayah perkampungan yang sama.

Meskipun begitu, penulis melihat ada beberapa faktor yang berpotensi menghambat proses pembelajaran peserta didik disana. Dari hasil wawancara dengan perwakilan guru serta peserta didik, beberapa faktor tersebut sebagian besar disebabkan oleh kurangnya motivasi dari peserta didik itu sendiri dalam mengikuti kegiatan pembelajaran, diantaranya seperti tidak mencatat penjelasan dari guru, terlambat mengerjakan tugas, sengaja datang terlambat ketika masuk kelas, maupun dalam beberapa kesempatan mencari-cari alasan serta celah untuk meninggalkan kegiatan pembelajaran. Walaupun pihak sekolah sudah melakukan beberapa penindakan, tetapi hal tersebut kerap kali terulang kembali dengan alasan para oknum peserta didik berada dalam fase remaja yang sedang melakukan pencarian jati diri.

Beberapa penelitian terdahulu yang disebutkan diatas hanya meneliti pengaruh dari variabel religiusitas maupun lingkungan sekolah terhadap motivasi peserta didik dalam mempelajari satu mata pelajaran saja, sehingga diperlukan adanya penelitian lanjutan yang membahas tentang pengaruh dari variabel religiusitas maupun lingkungan sekolah terhadap motivasi peserta didik dalam menjalani kegiatan pembelajaran di sekolah secara umum, tidak terfokus pada satu mata pelajaran saja sehingga dapat melengkapi hasil penelitian yang terdapat pada penelitian terdahulu.

\section{METODE PENELITIAN}

Berdasarkan

pendekatan penelitian, penelitian ini tergolong dalam penelitian kuantitatif dengan menggunakan metode penelitian ex post facto. Populasi dalam penelitian ini berasal dari seluruh siswa di kelas XI SMA NU Bancar tahun ajaran 2020/2021 di semua jurusan yang berjumlah 46 siswa. Sampel dalam penelitian ini ditentukan menggunakan metode sampling jenuh.

Dalam mengumpulkan data, peneliti menggunakan teknik berupa menyebarkan kuisioner yang berisi pertanyaan yang kemudian akan diisi oleh siswa sebagai responden. Indikator yang digunakan untuk mengukur variabel religiusitas diadaptasi dari penelitian Joseph \& DiDuca (2007) yaitu: kekhusyukan, keyakinan, keterlibatan emosional, dan bimbingan hidup. Indikator untuk mengukur variabel Lingkungan sekolah diadaptasi dari penelitian Wang \& Holcombe (2010) yang meliputi: struktur tujuan kinerja sekolah, struktur tujuan penguasaan belajar di sekolah, bimbingan kemandirian siswa, perkenalan kegiatan diskusi bagi 
siswa, dan dukungan sosial guru. Sedangkan indikator yang digunakan untuk megukur variabel motivasi belajar diadaptasi dari penelitian Garcia (1996) yang meliputi: orientasi tujuan intrinsik pembelajaran, orientasi tujuan ekstrinsik pembelajaran, aspek yang terkandung dalam penugasan, sikap keyakinan dalam belajar, efikasi diri dalam kinerja belajar, dan kecemasan dalam menghadapi ujian.

Dalam melakukan Uji hipotesis, peneliti menggunakan metode regresi linear berganda menggunakan bantuan software SPSS. Penelitian ini menguji hipotesis sebagai berikut: (H1) Terdapat Pengaruh Religiusitas Terhadap Motivasi Belajar Siswa serta (H2) Terdapat Pengaruh Religiusitas Terhadap Motivasi Belajar Siswa.

\section{HASIL DAN PEMBAHASAN}

\section{A. Hasil Penelitian}

\section{Uji Asumsi Klasik}

Setelah peneliti melaksanakan uji asumsi klasik, dapat disimpulkan bahwa data penelitian memliliki distribusi yang normal dengan nilai Asymp. Sig. (2-tailed) variabel Religiusitas, lingkungan sekolah dan motivasi belajar berturut-turut yaitu 0,$208 ; 0,145 ; 0,063$ yang semuanya lebih besar dari nilai alpha $(0,05)$. Data penelitian juga bersifat linier berdasarkan perolehan nilai Deviation from Linearity berjumlah $0,572 \geq 0,05$.

Data penelitian bebas multikolinearitas dengan perolehan nilai Tolerance dan Variance Inflation Factor (VIF) pada variabel religiusitas dan lingkungan sekolah yang samasama memiliki nilai sebesar 0,675 dan 1,482. Lebih besar dari yang disyaratkan yaitu nilai tolerance > 0,1 dan nilai VIF $<10$. Data penelitian ini juga Bebas Heteroskedastisitas dengan perolehan nilai signifikansi variabel Religiusitas, lingkungan sekolah dan motivasi belajar berturut-turut yang berjumlah 0,104 dan $0,455 \geq 0,05$. Sehingga data penelitian dapat digunakan untuk melakukan uji hipotesis.

\section{Uji Hipotesis}

Tabel 1. Hasil Pengujian Hipotesis

\begin{tabular}{lcccc}
\hline \multicolumn{1}{c}{ Variabel } & $\begin{array}{c}\text { T } \\
\text { Hitung }\end{array}$ & $\begin{array}{c}\text { T } \\
\text { Tabel }\end{array}$ & Sig & R2 \\
\hline Religiusitas & 4,313 & 2,017 & 0,000 & 0,297 \\
$\begin{array}{l}\text { Lingkunga } \\
\text { n Sekolah }\end{array}$ & 7,142 & 2,017 & 0,000 & 0,537 \\
\hline
\end{tabular}

Berdasarkan tabel diatas diperoleh nilai signifikansi Pengaruh Religiusitas Terhadap Motivasi Belajar adalah 0,000 < 0,05 serta nilai $\mathrm{T}$ Hitung berjumlah 4,313, > nilai $\mathrm{T}$ Tabel 2,017. Sehingga Ho ditolak dan H1 diterima. Yang berarti variabel Religiusitas memiliki pengaruh Terhadap Motivasi Belajar pada siswa kelas XI SMA NU Bancar.

Sedangkan nilai signifikansi Pengaruh Lingkungan Sekolah Terhadap Motivasi Belajar adalah $0,000<0,05$ serta nilai $\mathrm{T}$ Hitung yang berjumlah 7,142, > nilai $\mathrm{T}$ Tabel 2,017. Sehingga Ho ditolak dan $\mathrm{H} 2$ diterima. Yang berarti variabel Lingkungan Sekolah memiliki pengaruh Terhadap Motivasi Belajar pada siswa kelas XI SMA NU Bancar.

Nilai $\mathrm{R}$ Square yang diperoleh dari Pengaruh Religiusitas Terhadap Motivasi Belajar adalah 0,297, hal tersebut dapat diartikan bahwa variabel Religiusitas memiliki pengaruh sebesar 29,7\% Terhadap Motivasi Belajar, sedangkan $70,3 \%$ sisanya dipengaruhi oleh faktor lain. 
Sedangkan Nilai R Square yang diperoleh dari Pengaruh Lingkungan Sekolah Terhadap Motivasi Belajar adalah 0,537, hal tersebut dapat diartikan bahwa variabel Lingkungan Sekolah memiliki pengaruh sebesar $53,7 \%$ Terhadap Motivasi Belajar, sedangkan $\quad 46,3 \% \quad$ sisanya dipengaruhi oleh faktor lain.

\section{B. Pembahasan}

\section{Pengaruh Religiusitas terhadap Motivasi Belajar}

Setelah melalui proses pengujian, diperoleh hasil bahwa variabel Religiusitas berpengaruh signifikan Terhadap Motivasi Belajar pada para siswa. Hasil tersebut sesuai dengan Hadits Nabi Muhammad SAW yang diriwayatkan oleh Ibnu Majah, yaitu:

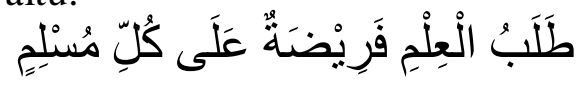
Menuntut ilmu merupakan

kewajiban bagi seluruh umat muslim (HR. Ibnu Majah)

Hasil penelitian tersebut juga sejalan dengan penelitian Nugrahini (2013) dengan kesimpulan bahwa religiusitas memiliki pengaruh kuat terhadap motivasi belajar. Hal ini dikarenakan menuntut ilmu merupakan kewajiban bagi seorang muslim. Seseorang yang faham akan kewajiban dalam menuntut ilmu akan secara otomatis faham terhadap kosekuensi dalam menjalankan kewajiban tersebut, yaitu akan mendapatkan balasan berupa pahala serta ridho dari Allah SWT. Maka dari itu, kegiatan belajar bagi seseorang yang memiliki sikap religiusitas tinggi dianggap sebagai bukan hanya sekadar menjalankan rutinitas sebagai peserta didik semata, melainkan dianggap juga sebagai media untuk mengharap ridho Allah SWT sehingga motivasi tersebut akan muncul secara otomatis dalam diri mereka. Amin (2020) dalam penelitiannya juga menyarankan pendidik supaya berperan aktif dalam menanamkan nilai-nilai religius kepada peserta didik, hal tersebut dimaksudkan supaya nilainilai religius yang ditanamkan tersebut dapat memotivasi para peserta didik dalam menjalani kegiatan pembelajaran sehingga mendapatkan prestasi yang baik dalam belajar.

\section{Pengaruh Lingkungan Sekolah Terhadap Motivasi Belajar}

Setelah melalui proses pengujian, diperoleh temuan bahwa Variabel Lingkungan Sekolah berpengaruh signifikan Terhadap Motivasi Belajar pada para siswa. Hasil tersebut sesuai dengan teori dari Sadirman (2009) yang menyebutkan bahwa salah satu faktor yang dapat mempengaruhi motivasi belajar adalah lingkungan belajar, yang mencakup lingkungan sekolah. Teori tersebut didukung oleh pendapat Yusuf (2012:54) yang mengatakan bahwa sekolah merupakan tempat dilaksanakannya sebuah kegiatan pendidikan secara sistematis untuk memberikan ilmu pengetahuan serta membantu mengasah potensi yang ada pada diri peserta didik.

Hodo (2016) mengatakan Guru dan kepala sekolah memiliki tanggung jawab yang besar untuk memotivasi peserta didik dalam menjalani kegiatan pembelajaran di sekolah. Mereka harus memahami bahwa Peserta didik mempunyai tingkat asimilasi yang berbeda satu sama lain, oleh karena itu, dibutuhkan teknik yang berbeda dalam situasi belajarmengajar berdasarkan karakteristik masing-masing peserta didik. 
Nurfirdaus \& Hodijah (2018) juga menyatakan bahwa dalam melaksanakan kegiatan pembelajaran, guru harus senantiasa menyampaikan nasihat, nasehat tersebut tidak cukup hanya dengan ssekadar perkataan, akan tetapi harus disertai dengan sebuah tindakan sehingga peserta didik akan termotivasi dalam menjalankan nasihat oleh sang guru tersebut. Oktaviana (2015) menambahkan guru juga harus mampu menciptakan relasi yang harmonis dengan peserta didik untuk mempermudah guru dalam mencapai tujuan pembelajaran yang diinginkan. Dalam sebuah relasi yang harmonis, peserta didik yang menyukai kepribadian seorang guru, cenderung akan menyukai mata pelajaran yang diajarkan sang guru juga sehingga mereka akan termotivasi untuk mempelajari materi yang disampaikan.

Hasil penelitian diatas sejalan dengan penelitian dari Mantilia (2019) yang menghasilkan kesimpulan bahwa kondisi lingkungan sekolah mempunyai pengaruh signifikan terhadap motivasi belajar peserta didik, karena dalamnya terdapat unsur lingkungan sosial dan non sosial yang dapat menentukan tingkat tinggi rendahnya motivasi peserta didik dalam menjalani kegiatan pembelajaran. Peserta didik akan belajar dengan tenang, tekun dan bersemangat apabila berada pada lingkungan yang memiliki suasana yang kondusif. Palangda (2017) dalam penelitiannya menyarankan kepada pihak sekolah untuk senantiasa menjalin hubungan yang harmonis dengan para peserta didik, melengkapi peralatan penunjang kegiatan pembelajara, melakukan pembaruan kurikulum, mempertahankan kedisiplinan sekolah dan meningkatkan kualitas infrastruktur pendidikan agar motivasi belajar peserta didik juga akan meningkat.

\section{PENUTUP}

Berdasarkan hasil penelitian yang telah dilaksanakan mengenai Pengaruh Religiusitas dan Lingkungan Sekolah terhadap Motivasi Belajar pada peserta didik XI SMA NU Bancar, maka diperoleh kesimpulan bahwa:

1. Pada pengujian $\mathrm{H} 1$, diperoleh nilai signifikansi $0,000<0,05$ dengan nilai $\mathrm{T}$ Hitung berjumlah 4,313> nilai $\mathrm{T}$ Tabel (2,01669), serta nilai R Square sebesar 0,297. Sehingga dapat disimpulkan bahwa Tingkat religiusitas mempunyai pengaruh yang rendah $(29,7 \%)$ terhadap motivasi belajar peserta didik di kelas XI SMA NU Bancar.

2. Pada pengujian $\mathrm{H} 2$, diperoleh nilai signifikansi $0,000<0,05$ serta nilai $\mathrm{T}$ Hitung yang berjumlah 7,142, > nilai $\mathrm{T}$ Tabel 2,01669, nilai $\mathrm{R}$ Square sebesar 0,537. Sehingga dapat disimpulkan bahwa lingkungan sekolah mempunyai pengaruh yang sedang $(53,7 \%)$ terhadap motivasi belajar peserta didik di kelas XI SMA NU Bancar.

Berdasarkan hasil penelitian dan saran yang telah disebutkan diatas, maka peneliti memberikan saran sebagai berikut:

1. Tingkat religiusitas mempunyai pengaruh yang rendah terhadap motivasi belajar peserta didik di kelas XI SMA NU Bancar. Maka upaya yang dilaksanakan untuk meningkatkannya adalah para guru di sekolah diharapkan dapat menanamkan nilai-nilai religiusitas dalam setiap materi pembelajaran yang disampaikan kepada para peserta didik, sehingga para peserta didik dapat menyadari tentang pentingnya menuntut ilmu yang dapat 
meningkatkan motivasi mereka dalam menjalani kegiatan pembelajaran di sekolah.

2. Lingkungan sekolah mempunyai tingkat pengaruh yang sedang terhadap motivasi belajar peserta didik di kelas XI SMA NU Bancar. Maka upaya yang dilaksanakan untuk meningkatkannya adalah pihak sekolah diharapkan dapat menciptakan sebuah ekosistem pembelajaran secara harmonis yang dapat mengakomodir segala kebutuhan dalam kegiatan pembelajaran, sehingga dapat memotivasi para peserta didik untuk menjalani kegiatan pembelajaran di dalamnya.

\section{DAFTAR PUSTAKA}

Amin, M. (2020). Hubungan Motivasi Religius Dengan Peningkatan Prestasi Belajar Peserta Didik. Inspiratif Pendidikan, 9(1), 31. https://doi.org/10.24252/ip.v9i1.1375 2

Garcia, T. (1996). Alternatives in Assessment of Achievements, Learning Processes and Prior Knowledge. In Alternatives in Assessment of Achievements, Learning Processes and Prior Knowledge. https://doi.org/10.1007/978-94-0110657-3

Guven, M. (2013). Relation of Motivation and Religiosity: an Empirical Research on the Relation of Academic Motivation and Intrinsic Religious Motivation. EkevAkademiDergisi, 17(55), 151165. Retrieved from http://ezproxy.lib.ucalgary.ca/login?u $\mathrm{rl}=\mathrm{http}: / /$ search.ebscohost.com/login. asp $x$ ?direct $=$ true $\& d b=a 9 h \& A N=949$ $00797 \&$ site $=$ ehost-live

Joseph, S., \& DiDuca, D. (2007). The Dimensions of Religiosity Scale: 20- item self-report measure of religious preoccupation, guidance, conviction, and emotional involvement. Mental Health, Religion and Culture, 10(6), 603-608.

https://doi.org/10.1080/13674670601 050295

Mantilia, J. (2019). PENGARUH LINGKUNGAN SEKOLAH TERHADAP MOTIVASI BELAJAR SISWA PADA MATA PELAJARAN PENDIDIKAN AGAMA ISLAM DI SMAN 1 KIBANG. IAIN Metro Lampung.

Nashori, F., \& Mucharam, R. D. (2002). Mengembangkan Kreatifitas dalam Perspektif Psikologi Islami. Yogyakarta: Menara Kudus Jogjakarta.

Nugrahini, A. D. (2013). Hubungan Antara Religiusitas Dengan Motivasi Belajar PAI Siswa Kelas XI SMA IT Abu Bakar Yogyakarta. Naskah Publikasi Universitas Muhammadiyah Surakarta, 1-11.

Nurfirdaus, N., \& Hodijah, N. (2018). STUDI TENTANG PERAN LINGKUNGAN SEKOLAH DAN PEMBENTUKAN PERILAKU SOSIAL SISWA SDN 3 CISANTANA. Jurnal Ilmiah Educater, 4(2), 113-129.

Oktaviana, I. (2015). Pengaruh Lingkungan Sekolah terhadap motivasi belajar siswa kelas V Sekolah Dasar di daerah Binaan I Kecamatan Limpung Kabupaten Batang. Universitas Negeri Semarang. (Thesis)

Palangda, L. (2017). Pengaruh Lingkungan Sekolah dan Lingkungan Keluarga terhadap Minat Belajar Ekonomi Peserta Didik di SMKN 4 Makassar. Universitas Negeri Makassar. (Thesis)

Saputri, R. U., Aminuyati, \& Achmadi. 
(2015). Pengaruh Lingkungan Keluarga Terhadap Motivasi Belajar Siswa Pada Pelajaran Ekonomi Di SMKN 3 Pontianak. Jurnal Pendidikan Dan Pembelajaran Khatulistiwa, 4(8), 1-12. Retrieved from

http://jurnal.untan.ac.id/index.php/jp $\mathrm{dpb} /$ article/view/11132

Sardiman. (2018). Interaksi dan Motivasi Belajar Mengajar. Depok: PT. Raja Grafindo Persada.

Tohidi, H., \& Jabbari, M. M. (2012). The Effects of Motivation in Education. Procedia Social and The Effects of Motivation in Education, 31(2011), 820-824.

https://doi.org/10.1016/j.sbspro.2011. 12.148

Wahyuningsih, H. (2008). Religiusitas, Spiritualitas, Dan Kesehatan Mental: Meta Analisis. Psikologika: Jurnal Pemikiran Dan Penelitian Psikologi, 13(25).

https://doi.org/10.20885/psikologika. vol13.iss 25 .art6

Wang, M. Te, \& Holcombe, R. (2010). Adolescents' perceptions of school environment, engagement, and academic achievement in middle school. American Educational Research Journal, 47(3), 633-662. https://doi.org/10.3102/00028312093 61209

Werang, B. R. (2018). Investigating students, learning motivation in Indonesian higher institution: A study from Musamus University of Merauke , Papua. International Journal of Development and Sustainability, 3, 1038-1048.

Wlodkowski, R., \& Jaynes, J. (2004). Hasrat Untuk Belajar: Membantu Anak-Anak Termotivasi dan Mencintai Belajar. Yogyakarta: Pustaka Belajar.

Yusuf, S. (2012). Psikologi Perkembangan Anak dan Remaja. Bandung: PT. Remaja Rosda Karya. 